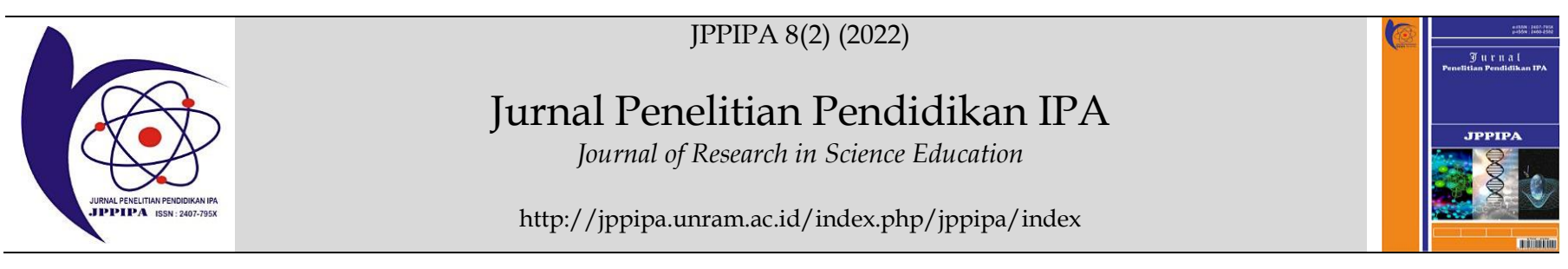

\title{
Secondary School Science Teacher Response to Minimum Competency Assessment: Challenges and Opportunities
}

\author{
Sri Yamtinah ${ }^{1 *}$, Budi Utami ${ }^{1}$, Mohammad Masykuri ${ }^{1}$, Bakti Mulyani, Maria ulfa ${ }^{1}$, Ari Syahidul \\ Shidiq ${ }^{1}$ \\ ${ }^{1}$ Chemistry Education, Sebelas Maret University, Surakarta, Indonesia
}

DOI: $\underline{10.29303 / \text { jppipa.v8i1.1075 }}$

\section{Article Info}

Received: October 30, 2021

Revised: January 5, 2022

Accepted: January 8, 2022

Published: January 31, 2022

\begin{abstract}
Teachers have an essential role in preparing students for Minimum Competency Assessment (MCA) or Asesmen Kompetensi Minimum (AKM). It takes preparation, readiness, and a good teacher's perception of the AKM so that the implementation of this program goes well. This study aims to analyze teachers' perceptions in secondary schools related to the opportunities and challenges of implementing AKM. A total of 66 secondary school science teachers participated as respondents in this study. Respondents in this study were randomly selected based on their willingness to fill out a given survey. The data collection instruments were six open-ended questions. This instrument is distributed online using Google Forms. The data obtained were then analyzed qualitatively and quantitatively. The results of this study reveal that the majority of science teachers have the perception that AKM policy is appropriate and suitable for implementation. However, the availability of supporting facilities and ICT literacy of students and teachers is considered a challenge that must be met. On the other hand, AKM and National Assessment (NA) are considered opportunities to improve the quality of education both nationally and locally in schools. This research is expected to reference the perception of science teachers about the challenges and opportunities for implementing AKM policies in junior high schools.
\end{abstract}

Keywords: Minimum Competency Assessment; teacher's perception; Survey; science teacher

Citation: Yamtinah, S., Utami, B., Masykuri, M., Mulyani, B., Ulfa, M., \& Shidiq, A.S. (2022). Secondary School Science Teacher Response to Minimum Competency Assessment: Challenges and Opportunities. Jurnal Penelitian Pendidikan IPA, 8(1), 124-131. https://doi.org/10.29303/jppipa.v8i1.1075

\section{Introduction}

Starting in 2021, the National Examination will be replaced with a National Assessment, containing a Minimum Competency Assessment (AKM) and Character and Learning Environment Survey. This new assessment is specifically designed for the function of mapping and improving the quality of education nationally. The substitute competency assessment for the National Examination will be designed so as not to have consequences for students. For example, implementation in the middle of the level (not the end of the level) makes the AKM results irrelevant for assessing student achievement. The results are also not relevant for selection to enter a higher school level. Thus, this assessment will not be an additional burden for students (Assessment and Learning Center of research and development agency and bookmaking ministry of education and culture, 2020a). The form of AKM questions is a form of cross-competency, crossfield and cross-subject questions. No longer distinguishes subjects significantly but sees a competency as a complete picture of a puzzle of various subjects.

The AKM assessment includes an assessment of reading and numeracy literacy. Reading literacy assesses the ability to reason using language, while numeracy assesses the ability to reason using 
mathematical logic (Cahyanovianty, 2021). Reading literacy is not just the ability to read literally without knowing the meaning of the reading, but the ability to understand reading concepts. Meanwhile, numeracy is not just the ability to count, but the ability to apply the concept of counting in a context, both abstract and real (Hasanah \& Sholihah, 2017; Peters, et al., 2017; Valiandes, 2015).

AKM can map students' reading literacy and numeracy skills in grades 5,8 , and 11 , which can be used to improve the learning process in the education unit. Therefore, the questions developed for AKM are contextual, take various forms of questions, measure problem-solving competence, and stimulate students to think critically. Assessment in AKM refers to the benchmarks contained in the Program for International Student Assessment (PISA) and Trends in International Mathematics and Science Study (TIMSS) (OECD, 2014, 2015; Education Assessment Center of Research and Development Agency, 2016). AKM questions will make students generate analytical skills based on information, not make students memorize/remember the material.

AKM results report will be made so that teachers and schools can use it to improve the teaching and learning process. This is possible because the AKM will be based on a learning progression model that will show the position of students in the stages of development of competency (Rokhim et al., 2021). The assessment report will also be designed so as not to pose a threat to teachers and schools. The government realizes that good and bad student achievement is influenced by teaching factors (processes at school) as well as factors outside of school, such as the home environment and parenting styles. Therefore, the success of teachers or schools will not be judged based on the level of competence of students at one time (Assessment and Learning Center of research and development agency and bookmaking ministry of education and culture, 2020b).

Teachers have an essential role in preparing students for AKM. Teachers are indirectly required to familiarize the forms of AKM questions in the learning and assessment processes. For that, it takes preparation, readiness and a good perception of the teacher towards AKM. Teachers' perceptions of AKM will affect the way they carry out learning in the classroom (Shidiq, et al., 2020a, 2020b; Shidiq \& Yamtinah, 2019). Teachers who have negative perceptions usually transfer their negative perceptions to students (Adams \& Krockover, 1997; Haney, et al, 2002; Harlen \& Holroyd, 2007; Ucar, 2012).

Several studies on teachers' knowledge and perceptions of AKM have been carried out, such as research on perceptions and readiness of elementary school teachers in dealing with AKM (Rohim, 2021), analysis of junior high school teachers' understanding of AKM (Fauziah, et al, 2021), and other research on teacher knowledge and skills for dealing with AKM (Anas, et al, 2021; Tju \& Murniarti, 2021). Based on previous research, the perception of science teachers in secondary schools regarding the opportunities and challenges of implementing AKM is still rarely explored. Therefore, this study aims to analyze teachers' perceptions in secondary schools related to the opportunities and challenges of implementing AKM. In this study, there are two formulations of problems: 1) What are the teachers' perceptions of the opportunities and challenges of implementing AKM?; and 2) What is their perception of the role of science teachers in AKM?. It is hoped that this research will reveal the opportunities and problems faced by teachers in preparing AKM.

\section{Method}

In this study, the survey method was used. A total of 66 secondary school science teachers participated as respondents. Respondents in this study were junior high school science teachers in Karanganyar district and were randomly selected based on their willingness to take part in the survey conducted. This survey was conducted online using the Google Forms platform. Six open-ended questions were used to reveal teachers' perceptions of the opportunities and challenges of implementing AKM. The data generated in this survey were analyzed qualitatively and quantitatively. The distribution of respondent data in this study is shown in Table 1.

Table 1. Distribution of Respondent Data

\begin{tabular}{lll}
\hline Respondent Data & & Percentage \% \\
\hline Gender & Male & 45.50 \\
& Female & 54.50 \\
Teaching experience (year) & $<5$ & 6.10 \\
& $6-10$ & 3 \\
& $11-15$ & 9 \\
& $16-20$ & 18.20 \\
& $>20$ & 63.70 \\
School status & Public & 83.30 \\
& Privat & 17.70 \\
Experience participating in & Yes & 46.90 \\
AKM socialization/training & No & 53.10 \\
\hline
\end{tabular}

\section{Result and Discussion}

Teachers' perceptions toward the opportunities and challenges of AKM

The government has formulated a policy to replace the national exam with a national assessment consisting of a minimum competency assessment 
(AKM), and character and learning environment survey, which will be carried out in 2021. This policy indirectly resembles the Program for International Student Assessment (PISA). A project of OECD (Organization for Economic Cooperation and Development) member countries (OECD, 2016a). PISA is a three-year international assessment designed to evaluate education systems worldwide by testing the skills and knowledge of students who are about to end compulsory education at around 15 years of age. The assessment determines whether students can apply knowledge and examines students' estimates of the knowledge learned and the ability to apply the knowledge in real life (Yaffe \& Burg, 2018).

Every three years, students complete an assessment including Reading Literacy, Mathematical Literacy and Science Literacy test items. Students also completed extensive background questionnaires, and principals completed surveys describing the educational context in their schools, including the level of resources in the school, staff qualifications and teacher morale. Data collected from the assessment and the background questionnaire were analyzed, and the results were published a year after the assessment. Competency-based PISA assessments are designed to help governments monitor educational system outcomes in terms of student achievement regularly and within a common internationally accepted framework. PISA results make it possible to compare how students in participating countries perform a standard set of tasks. In this way, PISA helps governments understand and improve the effectiveness of the education system and learn from other countries' educational practices (OECD, 2016a). In addition, it can also help policymakers use PISA results to make decisions about Education and set new targets. In the context of the National Assessment and AKM, which will be implemented in 2021, adapting the concept of the assessment and survey conducted by PISA. The implementation of this policy also creates various perceptions in Science Teachers. The survey results on the perception of science teachers on this issue are shown in Figure 1.

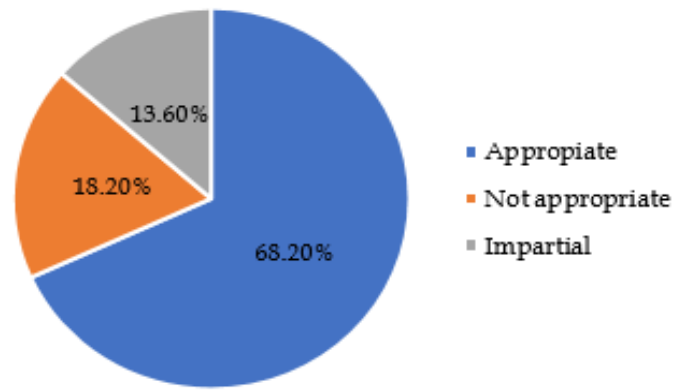

Figure 1. Science Teacher's Perception of the Implementation of the AKM
In general, as many as $68.2 \%$ of science teachers perceive that the policy of implementing the National Assessment and AKM that adopts PISA is following the Indonesian context. However, as many as $18.2 \%$ of respondents think that this AKM policy is inappropriate for the Indonesian context. Thus, in addition to teachers' perceptions of the implementation of AKM policies, this study also revealed science teachers' opinions about the advantages and disadvantages of AKM implementation (Table 2 and Table 3).

Table 2. Advantages of AKM

\begin{tabular}{ll}
\hline Respondent & Advantages of AKM \\
\hline Teacher A & $\begin{array}{l}\text { AKM and AN can map the quality of } \\
\text { education specifically in education units }\end{array}$ \\
Teacher B & $\begin{array}{l}\text { Familiarize students to find solutions to real } \\
\text { everyday problems }\end{array}$ \\
Teacher C & $\begin{array}{l}\text { AKM and AN not only measure students' } \\
\text { cognitive abilities but also measure affective } \\
\text { aspects and learning environment. }\end{array}$ \\
Teacher D & $\begin{array}{l}\text { It can be used as an annual evaluation } \\
\text { material for schools regarding students' } \\
\text { conditions and learning environment. }\end{array}$ \\
Teacher E & $\begin{array}{l}\text { Increase students' creativity, be able to read } \\
\text { and analyze events around them and find } \\
\text { solutions. }\end{array}$ \\
\hline
\end{tabular}

Table 3. Disadvantages of AKM

\begin{tabular}{ll}
\hline Respondent & Advantages of AKM \\
\hline Teacher A & $\begin{array}{l}\text { Information technology infrastructure in } \\
\text { each region is different. Therefore, the } \\
\text { sampling of AKM participants is not evenly } \\
\text { distributed. }\end{array}$ \\
Teacher B & $\begin{array}{l}\text { Not being used as a benchmark like } \\
\text { graduation tends to make students ignore } \\
\text { this kind of exam. }\end{array}$ \\
Teacher C & $\begin{array}{l}\text { Does not reflect the complete learning } \\
\text { success. } \\
\text { Tend not to be related to curriculum } \\
\text { material } \\
\text { Teacher E }\end{array}$ \\
Not every subject leads to reading and \\
numeracy literacy.
\end{tabular}

The adaptation of PISA for the AKM program allows this assessment to be used by the government and education units to map the quality of education and learning. This is also in line with the respondent's perception that a complex AN assessment that includes students, teachers and principals can be used as a benchmark to map the quality of education. In addition, the AKM not only focuses on students' cognitive abilities in subjects but also on their skills and knowledge to solve real-world problems, affective aspects and the learning climate in schools. In addition, there are also teachers' perceptions of the disadvantages of the AKM policy. In table 3, the 
teachers think that AKM that is carried out randomly and uses computer equipment will cause disparities in various regions in Indonesia. Not all schools in Indonesia have good ICT facilities (Ciptaningrum, 2017). In addition, teachers assume that not all subjects have numeracy literacy and reading literacy. So that the role of the teacher to contribute to this is felt to be lacking. In addition to the advantages and disadvantages of AKM implementation, teachers were also asked their perceptions of the challenges of implementing AKM policies. The results of this survey are shown in Table 4.

Table 4. The Challenges of Implementing AKM

\begin{tabular}{ll}
\hline Respondent & Advantages of AKM \\
\hline Teacher A & $\begin{array}{l}\text { The results obtained are not following the } \\
\text { actual conditions }\end{array}$ \\
Teacher B & $\begin{array}{l}\text { Availability of supporting facilities and } \\
\text { infrastructure such as computer laboratories }\end{array}$ \\
Teacher C & $\begin{array}{l}\text { How to teach AKM to students. } \\
\text { Teacher D }\end{array}$ \\
Teacher E & Contribution of the role of subject teachers \\
\hline
\end{tabular}

Based on table 4. Science teachers think that ICT literacy and supporting facilities in the Indonesian archipelago can be a challenge for AKM implementation. ICT literacy is felt to be influential because AKM is conducted online using a computer. If students and teachers have not mastered the use of computers and ICT, it is feared that they will interfere with the implementation of AKM. Teachers' technological knowledge can improve student learning outcomes (Nawzad, et al, 2018). When technology is used properly, it will bring many benefits. This knowledge of technology involves the skills required to operate a particular technology. In the case of digital technology, this includes knowledge of operating systems and computer hardware and the ability to use the software. In addition, knowledge of technology also shows how often teachers follow technological developments (Dalal, et al., 2017; Holland \& Piper, 2016; Koh, et al., 2010; Koh \& Chai, 2016).

Implementing online learning during a pandemic that requires technology by both teachers and students has a positive impact on their ICT mastery (Kartimi, et al., 2021). These results affect the implementation of AKM which requires ICT skills. This can be a provision in preparing themselves for the future, especially for students. Students with good ICT literacy will affect their self-efficacy (Prior, et al., 2016; Tayag, 2020). Using technology in online learning can also increase student activity (Huang, et al., 2019; Mrani, et al., 2020). Teachers must understand which technologies are best suited to address these subjects and how content determines or shapes the use of specific educational technologies, and vice versa (Harris, et al, 2009).

\section{Perceptions about the role of science teachers in AKM}

One of the differences between AN and PISA is in scientific literacy. PISA directly assesses scientific literacy, but AKM does not. Reading literacy, Mathematical literacy, and Scientific literacy are the three cognitive areas assessed in PISA. However, in each three-year cycle, one cognitive area is the main focus of the assessment, with most items focusing on that area and fewer items on the other two areas. As in 2015, which focused on scientific literacy, and 2018 on reading literacy (OECD, 2019). Scientific literacy in PISA 2015 was divided into four aspects: context, content, knowledge, and attitude, while in 2018, there were only three aspects without the attitude aspect. In addition to these areas, students are also tested in innovative domains such as collaborative problem solving in 2015 and global competence in 2018 (OECD, 2016b, 2019).

Scientific literacy is the ability to deal with issues related to science and scientific ideas (Holbrook, 2010; OECD, 2016a). Scientific literacy requires understanding scientific concepts and theories, the general procedures and practices associated with scientific inquiry, and how science drives progress. Therefore, individuals with scientific literacy understand the main concepts and ideas that form the basis of scientific and technological thinking; how the knowledge was acquired; and the extent to which this knowledge is justified by evidence or theoretical explanation (Choi, et al., 2011; Rennie \& Williams, 2002; Wei \& Thomas, 2005).

This definition of scientific literacy views scientific literacy as multidimensional, understanding science and more than that. PISA also emphasizes the importance of understanding the characteristics of science as scientific inquiry, understanding how science and technology shape the environment intellectually and culturally. Scientific literacy is considered a key learning outcome in education at the age of 15 for all students. The inclusion of scientific literacy as a general competence for life reflects the growing trend in scientific and technological aspects (OECD, 2019). This vital contribution of scientific literacy prompted this research to investigate science teachers' perceptions of AKM implementation. The results of the investigation are shown in table 5 . 
Table 5. Perceptions of the role of science teachers on AKM

\begin{tabular}{|c|c|}
\hline Respondent & Advantages of AKM \\
\hline Teacher A & $\begin{array}{l}\text { Science teachers start teaching using } \\
\text { contextual methods that refer to problem- } \\
\text { solving and apply HOTS practice questions. }\end{array}$ \\
\hline Teacher B & $\begin{array}{l}\text { Train students to think creatively by } \\
\text { presenting problems in learning to be } \\
\text { solved. }\end{array}$ \\
\hline Teacher C & $\begin{array}{l}\text { Directing the learning and assessment } \\
\text { process following the National Assessment }\end{array}$ \\
\hline Teacher D & $\begin{array}{l}\text { It provides learning in a science field and } \\
\text { integrates with other fields so that each } \\
\text { teacher in the field of study must } \\
\text { collaborate with other teachers. }\end{array}$ \\
\hline Teacher E & $\begin{array}{l}\text { Familiarize in learning the application of } \\
\text { character, process thinking and HOTS }\end{array}$ \\
\hline
\end{tabular}

Based on table 5. Science teachers think that they can prepare students for AN and AKM by directing the learning and assessment process to be more creative by presenting various contextual problems of everyday life. In addition, giving students contextual and HOTStype questions is also one of the choices for the contribution of science teachers. This is in line with the context of the PISA assessment. PISA 2018 evaluates scientific knowledge using a background that raises relevant questions, usually related to science education courses in participating countries. However, the assessment items are not limited to the school science background. Items in the 2018 PISA Scientific Assessment can relate to oneself, family, and peer groups (individuals), communities (local and national), or life around the world (global). In addition, the context may involve technology, or in some cases, historical elements may be used to assess students' understanding of the processes and practices involved in advancing scientific knowledge (Kartimi, et al, 2021; Klassen, 2006; O'Sullivan, 2006).

The project's background in the PISA scientific assessment is also divided into five scientific and technological applications: health and disease, natural resources, environmental quality, hazards, and the boundaries of science and technology. However, the PISA scientific assessment is not a background assessment. Instead, it evaluates abilities and knowledge in a specific context. However, the PISA science assessment is not a context assessment. Instead, it assesses competence and knowledge in a specific context. These contexts were chosen for their relevance to the interests and lives of students and because they are areas where scientific literacy has particular value in improving and maintaining the quality of life and in the development of public policy (OECD, 2016a, 2019).

The main goal of science teaching in secondary schools is for all students to have scientific literacy skills, as evidenced by the issuance of new standards on science content, pedagogy, and assessment (NRC, 1996; Shwartz, et al., 2005; Shwartz, et al., 2006). The term scientific literacy embodies scientific ideas, concepts, and practices in many disciplines. The general dimensions usually associated with scientific literacy are: (a) understanding the nature of science scientific norms and methods, and the nature of scientific knowledge; (b) understanding the main scientific concepts, principles, and theories (content science); (c) understand how the relationship between science and technology is interrelated; (d) respect and understand the impact of science and technology on society; (e) communication competence in a scientific context - the ability to read, write and understand systematic human knowledge; and (f) applying some scientific knowledge and reasoning skills in daily life (Shwartz, et al., 2005; Shwartz, Ben-zvi, et al., 2006; Shwartz, Ben-Zvi, et al., 2006).

Presenting a scientific context close to students' daily lives improves students' scientific literacy and trains students to be able to think HOTS (Brookhart, 2010; Shidiq, et al., 2021; Puspitasari \& Nugroho, 2020). Higher Order Thinking Skills (HOTS), according to Heong, et al. (2011) mentioned that it is a component of creative and critical thinking skills (Heong, et al., 2011). When students know how to use these two skills, it means students can apply higher-order thinking skills. All students can think, but most of them need encouragement and guidance for higher-order thinking processes. These higher-order thinking skills can be taught and learned. All students have the right to learn and apply thinking skills, like any other knowledge. Higher-order thinking skills are determined by the extent to which the mind is used for new challenges (Brookhart, 2010; King et al., 1998; Shidiq, et al., 2015).

The next step can be taken by knowing science teachers' perceptions about their contribution to the assessment of AN and AKM. Science teachers can apply what they think about implementing contextual learning that leads to HOTS. In addition, according to the findings of this study, teachers can also familiarize students with contextual question types and train them to use various types of ICT. This will indirectly increase students' scientific literacy and contribute to the assessment of students' reading and mathematical literacy in AKM

\section{Conclusion}

Various teachers responded to the opportunities and challenges of implementing AKM. The majority of science teachers have the perception that this policy is appropriate and suitable for implementation. However, 
some science teachers feel that this policy is not suitable for implementation in Indonesia. An archipelagic country with an uneven distribution of educational facilities to remote areas is a challenge for the implementation of AKM. In addition, the ICT literacy of students and teachers can be a challenge for AKM implementation. The contribution that science teachers can make to the success of the AKM implementation is to familiarize students with contextual learning and assessment processes following everyday life. Bringing real-world science problems to the learning and assessment process will contribute to the improvement of their science literacy and HOTS. This study is expected to contribute to providing a complete analysis of teacher perceptions of the MMR. The habit of using contextual instruments and HOTS is one of the recommendations of this study to familiarize students with AKM.

\section{Acknowledgements}

The authors would like to acknowledge the Institute of Research and Community Service (LPPM), Universitas Sebelas Maret, Surakarta, Indonesia, for providing grant funding for the research through The HGR Research 2021.

\section{References}

Adams, P.E. and Krockover, G.H. (1997), Beginning science teacher cognition and its origins in the preservice secondary science teacher program. J. Res. Sci. Teach., 34: 633-653. https://doi.org/10.1002/(SICI)10982736(199708)34:6<633::AID-TEA6>3.0.CO;2-O.

Anas, M., Muchson, M., Sugiono, S., \& Rr. Forijati. (2021). Pengembangan kemampuan guru ekonomi di Kediri melalui kegiatan pelatihan asesmen kompetensi minimum (AKM). Rengganis Jurnal Pengabdian Masyarakat, 1(1), 48-57. https://doi.org/10.29303/rengganis.v1i1.28

Assessment and Learning Center of research and development agency and bookmaking ministry of education and culture. (2020a). AKM dan Implikasinya pada Pembelajaran.

Assessment and Learning Center of research and development agency and bookmaking ministry of education and culture. (2020b). Tanya jawab AKM (Issue 14).

Brookhart, S. M. (2010). How To Assess HOTS In Your Classroom. ASCD publications.

Cahyanovianty, A., \& Wahidin, W. (2021). Analisis Kemampan Numerasi Peserta Didik Kelas VIII dalam Menyelesaikan Soal Asesmen Kompetensi
Minimum (AKM). Jurnal Cendekia : Jurnal Pendidikan Matematika, 5(2), 1439-1448. https://doi.org/10.31004/cendekia.v5i2.651.

Choi, K., Lee, H., Shin, N., Kim, S.-W., \& Krajcik, J. (2011). Re-conceptualization of scientific literacy in South Korea for the 21st century. Journal of Research in Science Teaching, 48(6), 670-697. https://doi.org/10.1002/tea.20424

Ciptaningrum, D. (2017). The Development of the Survey of Technology Use, Teaching, and Technology-Related Learning Experiences among Pre-Service English Language Teachers in Indonesia. Journal of Foreign Language Teaching and Learning, 2(2), 11-26. https://doi.org/10.18196/ftl.2220.

Dalal, M., Archambault, L., \& Shelton, C. (2017). Professional Development for International Teachers: Examining TPACK and Technology Integration Decision Making. Journal of Research on Technology in Education, 49(3-4), 117-133. https://doi.org/10.1080/15391523.2017.1314780

Education Assessment Center of Research and Development Agency. (2016). Trends in International Mathematics and Science Study, Result From TIMSS 2015. In Pusat Penilaian Pendidikan Badan Penelitian dan Pengembangan.

Fauziah, A., Sobari, E. F. D., \& Robandi, B. (2021). Analisis Pemahaman Guru Sekolah Menengah Pertama (SMP) Mengenai Asesmen Kompetensi Minimum (AKM). Edukatif: Jurnal Ilmu Pendidikan, 3(4), 1550-1558. https://doi.org/10.31004/edukatif.v3i4.608

Haney, J. J., Lumpe, A. T., Czerniak, C. M., \& Egan, V. (2002). From Beliefs to Actions: The Beliefs and Actions of Teachers Implementing Change. Journal of Science Teacher Education, 13(3), 171-187. https://doi.org/10.1023/A:1016565016116

Harlen, W., \& Holroyd, C. (2007). Primary teachers' understanding of concepts of science: impact on confidence and teaching. International Journal of Science Education, 19(1), 93-105. https://doi.org/10.1080/0950069970190107

Harris, J., Mishra, P., \& Koehler, M. (2009). Teachers' technological pedagogical content knowledge and learning activity types: Curriculum-based technology integration refrained. Journal of Research on Technology in Education, 41(4), 393-416. https://doi.org/10.1080/15391523.2009.10782536

Hasanah, M., \& Sholihah, R. Y. (2017). Correlation Between Reading Literacy Ability and Achievement in Learning Indonesian Languange in Grade X. Journal of Intensive Studies on Languange, Literature, Art, and Culture, 1(2). 83-88. http://dx.doi.org/10.17977/um006v1i22017p083

Heong, Y. M., Othman, W. B., Yunos, J. Bin, Kiong, T. 
T., Hassan, R. Bin, Mohaffyza, M., \& Mohamad, B. (2011). The Level of Marzano Higher Order Thinking Skills among Technical Education Students. International Journal of Social Science and Humanity, 1(2), 121-125. https://doi.org/10.7763/IJSSH.2011.V1.20

Holbrook, J. (2010). Education through science education for all. Science Education International, 21(2), 80-91.

Holland, D. D., \& Piper, R. T. (2016). Testing a Technology Integration Education Model for Millennial Preservice Teachers. Journal of Educational Computing Research, 54(2), 196-224. https://doi.org/10.1177/0735633115615129

Huang, B., Hwang, G. J., Hew, K. F., \& Warning, P. (2019). Effects of gamification on students' online interactive patterns and peer-feedback. Distance Education, $\quad 40(3), \quad 350-379$. https://doi.org/10.1080/01587919.2019.1632168

Kartimi, Gloria, R. Y., \& Anugrah, I. R. (2021). Chemistry online distance learning during the covid-19 outbreak: Do tpack and teachers' attitude matter? Jurnal Pendidikan IPA Indonesia, 10(2), 228240. https://doi.org/10.15294/jpii.v10i2.28468

Kartimi, Shidiq, A. S., \& Nasrudin, D. (2021). The elementary teacher readiness toward stem-based contextual learning in 21st century era. Elementary Education Online, 20(1), 145-156. https://doi.org/10.17051/ilkonline.2021.01.019

King, F. J., Goodson, L., \& Rohani, F. (1998). Higher Order Thinking Skills. Publication of the Educational Services Program, Now Known as the Center for Advancement of Learning and Assessment. Obtido de: Www.Cala.Fsu.Edu, 1176.

Klassen, S. (2006). Contextual assessment in science education: Background, issues, and policy. Science Education, 90(5), 820-851. https://doi.org/10.1002/sce.20150

Koh, J H L, Chai, C. S., \& Tsai, C. C. (2010). Examining the technological pedagogical content knowledge of Singapore pre-service teachers with a largescale survey. Journal of Computer Assisted Learning, 26(6), 563-573. https://doi.org/10.1111/j.13652729.2010.00372.x

Koh, Joyce Hwee Ling, \& Chai, C. S. (2016). Seven design frames that teachers use when considering technological pedagogical content knowledge (TPACK). Computers and Education, 102, 244-257. https://doi.org/10.1016/j.compedu.2016.09.003

Mrani, C. A., El Hajjami, A., \& El Khattabi, K. (2020). Effects of the Integration of PhET Simulations in the Teaching and Learning of the Physical Sciences of Common Core (Morocco). Universal Journal of Educational Research, 8(7), 3014-3025. https://doi.org/10.13189/ujer.2020.080730

Nawzad, L., Rahim, D., \& Wakil, K. (2018). The Effectiveness of Technology for Improving the Teaching of Natural Sciences. Indonesian Journal of Curriculum and Educational Technology Studies, 6(1), 15-21. https:// doi.org/10.15294/ijcets.v3i1.8675

NRC. (1996). National Science Education Standards (NSES). National Academic Press.

O'Sullivan, M. (2006). Lesson observation and quality in primary education as contextual teaching and learning processes. International Journal of Educational Development, 26(3), 246-260. https://doi.org/10.1016/j.ijedudev.2005.07.016

OECD. (2014). 2012 PISA Results. 98.

OECD. (2015). Education in Indonesia: Rising to the Challenge. https://doi.org/10.1787/9789264230750-en

OECD. (2016a). Assesing Scientific, Reading and Mathematical Literacy A Frame Work for PISA 2015. OECD Publishing.

OECD. (2016b). PISA 2015 Assessment and Analytical Framework PISA 2015 Assessment and Analytical Framework. In OECD Publishing.

OECD. (2019). PISA 2018 Assessment and Analytical Framework, PISA. In OECD Publishing.

Peters, E., Shoots-Reinhard, B., Tompkins, M. K., Schley, D., Meilleur, L., Sinayev, A., Tusler, M., Wagner, L., \& Crocker, J. (2017). Improving numeracy through values affirmation enhances decision and STEM outcomes. PLoS ONE, 12(7). https://doi.org/10.1371/journal.pone.0180674

Prior, D. D., Mazanov, J., Meacheam, D., Heaslip, G., \& Hanson, J. (2016). Attitude, digital literacy and self efficacy: Flow-on effects for online learning behavior. Internet and Higher Education, 29, 91-97. https://doi.org/10.1016/j.iheduc.2016.01.001

Puspitasari, Y. D., \& Nugroho, P. A. (2020). Peningkatan Higher Order Thinking Skill dan Kemampuan Kognitif pada Mahasiswa melalui Pendekatan Science, Environment, Technology and Society Berbantuan Modul Pembelajaran. Jurnal IPA \& Pembelajaran IPA, 4(1), 11-28. https://doi.org/10.24815/jipi.v4i1.14608

Rennie, L. J., \& Williams, G. F. (2002). Science Centers and Scientific Literacy: Promoting a Relationship with Science. Science Education, 86(5), 706-726. https://doi.org/10.1002/sce.10030

Rohim, S. R. I. D. G. D. C. (2021). Konsep Asesmen Kompetensi Minimum Meningkatkan Kemampuan Literasi Numerasi Sekolah Dasar untuk Siswa. Jurnal Varidika, 33(1), 54-62. https://doi.org/10.23917/varidika.v33i1.14993

Rokhim, D. A., Rahayu, B. N., Alfiah, L. N., Peni, R., Wahyudi, B., Wahyudi, A., Widarti, H. R., \& Malang, U. N. (2021). Analisis Kesiapan Peserta 
Didik Dan Guru Pada Asesmen Nasional ( Asesmen Kompetensi Minimum , Survey Karakter, Dan Survey Lingkungan Belajar ). Jurnal Administrasi Dan Manajemen Pendidikan, 4, 61-71.

http://dx.doi.org/10.17977/um027v4i12021p61

Shidiq, A. S., \& Yamtinah, S. (2019). Pre-service chemistry teachers' attitudes and attributes toward the twenty-first century skills. Journal of Physics: Conference Series, 1157(4), 042014. https://doi.org/10.1088/17426596/1157/4/042014

Shidiq, A. S., Masykuri, M., \& Susanti, E. (2015). Analisis Higher Order Thinking Skills (HOTS) Menggunakan Instrumen Two-Tier Multiple Choice Pada Materi Kelarutan Dan Hasil Kali Kelarutan Untuk Siswa Kelas Xi Sma N 1 Surakarta. Prosiding Seminar Nasional Pendidikan Sains, November, 2015-2159.

Shidiq, A. S., Permanasari, A., \& Hernani. (2020a). Chemistry Teacher's Perception toward STEM Learning. ACM International Conference Proceeding Series, 40-43. https://doi.org/10.1145/3392305.3396901

Shidiq, A. S., Permanasari, A., \& Hernani. (2020b). PreService and In-Service Chemistry Teachers' Views on Teaching Spectrometry in Senior High School. Journal of Engineering Science and Technology Special Issue on AASEC2019, AASEC(2019), 80.

Shwartz, Y., Ben-Zvi, R., \& Hofstein, A. (2005). The importance of involving high-school chemistry teachers in the process of defining the operational meaning of 'chemical literacy.' International Journal of Science Education, 27(3), 323-344. https://doi.org/10.1080/0950069042000266191

Shwartz, Y., Ben-zvi, R., \& Hofstein, A. (2006). Chemical Literacy: What Does This Mean to Scientists and School Teachers? Journal of Chemical Education, 83(10), 1557-1561. https://doi.org/10.1021/ed083p1557

Shwartz, Y., Ben-Zvi, R., \& Hofstein, A. (2006). The use of scientific literacy taxonomy for assessing the development of chemical literacy among highschool students. Chemistry Education Research and Practice, 7(4), 203-225. https://doi.org/10.1039/B6RP90011A

Tayag, J. R. (2020). Pedagogical Support for Blended Learning Classrooms: Interfacing Teacher and Student Perspectives. Universal Journal of Educational Research, 8(6), 2536-2541. https://doi.org/10.13189/ujer.2020.080637

Tju, M., \& Murniarti, E. (2021). Analisis Pelatihan Asesmen Kompetensi Minimum. Jurnal Dinamika Pendidikan, 14(2), 110-116.
Ucar, S. (2012). How Do Pre-Service Science Teachers ' Views on Science, Scientists, and Science Teaching Change Over Time in a Science Teacher Training Program? Journal of Science Education and Technology, 21, 255-266. https://doi.org/10.1007/s10956-011-9311-6

Valiandes, S. (2015). Evaluating the impact of differentiated instruction on literacy and reading in mixed ability classrooms: Quality and equity dimensions of education effectiveness. Studies in Educational Evaluation, 45, 17-26. https://doi.org/10.1016/j.stueduc.2015.02.005

Wei, B., \& Thomas, G. P. (2005). Rationale and Approaches for Embedding Scientific Literacy into the New Junior Secondary School Chemistry Curriculum in the People's Republic of China. International Journal of Science Education, 27(12), 1477-1493.

https://doi.org/10.1080/09500690500154129

Yaffe, Y., \& Burg, D. (2018). What more can we learn from PISA tests? A comparative analysis of the long-term dynamics of Israeli international educational achievements. International Education Journal, 17(4), 129-146 